\title{
“ BUDAYA MALU BAGI PEJABAT PUBLIK DALAM KISRUH LEMBAGA PENEGAK HUKUM (KPK VS POLRI)"
}

\author{
Oleh : Muh. Firyal Akbar \\ (Dosen Administrasi Negara Universitas Muhammadiyah Gorontalo)
}

\begin{abstract}
Kisruh yang terjadi antara dua lembaga yang notabene sebagai institusi penegak hukum di Negeri ini tengah disoroti, bukan karena prestasi dari kinerja dari dua lembaga ini namun karena keputusan-keputusan dari kedua lembaga yang kemudian melahirkan polemik yang hingga saat ini masih berlangsung. Dimulai dengan keputusan penetapan status tersangka calon tunggal Kapolri yang disodorkan Presiden Joko Widodo kepada DPR oleh Komisi Pemberantasan Korupsi (KPK) Komisaris Jenderal Budi Gunawan terkait dugaan kasus "rekening gendut" yang kemudian seakan menjadi pukulan telak bagi institusi Kepolisian, walaupun sehari setelah penetapannya DPR tetap melaksanakan uji kepatutan dan kelayakan (fit and Propert test) dan seakan berbuntut pada "Serangan" kepada pimpinan KPK yang juga ditetapkan sebagai tersangka, dari penangkapan wakil ketua KPK Bambang Wijayanto oleh Bareskrim Polri dengan dugaan kasus kesaksian palsu oleh seorang saksi pada sidang MK untuk perkara Pilkada KotaWaringin Barat, yang dimana pada saat itu Bambang sebagai lawyer dari pasangan salah satu calon Pilkada tersebut, penangkapannya juga atas laporan dari mantan calon Kepala Daerah Kota Waringin Barat. Tak cukup sampai disitu, beberapa pimpinan KPK termasuk Ketua KPK Abraham Samad tidak lama lagi juga akan ditetapkan sebagai Tersangka dalam kasus berbeda, yakni pertemuannya dengan para elite Partai Demokrasi Indonesia Perjuangan yang diungkapkan PLT Sekjen P-DIP Hasto Kristanto, yang didalamnya diduga berisi tawaran dari Ketua KPK dalam menyelesaikan ataupun meringankan kasus yang sementara KPK periksa, hingga dugaan kasus pemalsuan Dokumen Negara (KTP/Paspor) ketika Abraham Samad masih aktif di Makassar
\end{abstract}

\section{Etika Pejabat Publik Dalam Kisruh POLRI dan KPK}

Dalam tulisan yang akan penulis sajikan ini tidak akan membahas lebih jauh dan terperinci dari apa yang telah terjadi antara ke dua Lembaga penegak hukum ini, ataupun mengenai kronologinya lebih mendalam, namun yang penulis sajikan adalah hal-hal yang berkaitan dengan permasalahan Etika dari para pejabat Negara/Publik yang diduga terlibat dalam kekisruhan ini. Konsep etika sangat berkaitan dengan tingkah laku dari seseorang, apalagi untuk mereka yang diberi tugas sebagai pejabat publik, dalam menjalankan tugas dan fungsinya secara baik dan benar, melihat permasalahan mana yang salah dan mana yang benar, dan segala sesuatu yang berhubungan dengan kewajiban moral pejabat itu sendiri. Definisi Etika sendiri menurut Kamus Besar Bahasa Indonesia (KBBI) etika dibagi dalam tiga 
definisi etika, yakni ilmu mengenai apa yang baik dan buruk, kumpulan azas atau nilai, dan nilai mengenai benar dan salah. Sedangkan menurut $K$. Bertens, etika dalah nilai-nilai dan norma moral, yang menjadi pegangan bagi seseorang atau suatu kelompok dalam mengatur tingkah lakunya. Selanjutnya dalam perkembangannnya secara historis Prof.Dr. Jimly Asshiddiqie, SH, dalam tulisannya mengenai sejarah etika profesi dan jabatan publik, mengatakan tradisi membangun etika positif berupa prinsip-prinsip etika dan perilaku yang dirumuskan, sebagai standar yang diidealkan bagi para anggota suatu komunitas profesi atau jabatan tertentu yang membutuhkan kepercayaan publik, yang dimulai dari negara inggris dan sampai ke amerika, dimulai dari kode etik kedokteran, kode etik akuntan, sampai kepada kode etik hukum.

Dari penjelasan tersebut dapat terlihat bahwa Etika adalah salah satu hal penting dalam kehidupan sosial kemasyarakatan karena didalamnya terdapat nilai-nilai positif, yang tentunya Etika dari seseorang khususnya bagi mereka yang diberikan wewenang dalam suatu jabatan akan mencerminkan kemampuan dia sebagai seorang pemimpin dalam profesi kerja yang diberikan kepadanya.

\section{Budaya Malu Bagi Pejabat Publik Dalam Kisruh Polri vs KPK}

Kaitan dengan pembahasan Etika tentunya setiap pejabat publik sudah semestinya mengetahui apa yang harus mereka lakukan ketika ada permasalahan yang terjadi padanya baik secara pribadi maupun institusi, semestinya sebagai pejabat publik mereka sudah mengetahui langkah apa yang akan diambil yang akan menunjukkan sikap dia sebagai pemimpin yang mengerti etika, dan sedikit memiliki "rasa malu". Rasa malu atau "budaya malu" untuk pejabat publik yang sedang terlibat masalah atau kasus yang menyebabkan dirinya menjadi sorotan publik sebenarnya bukanlah hal yang kemudian dianggap rendah, justru budaya malu harus ditujukkan sebagai sikap kesatria dari seorang abdi Negara. Budaya malu yang dimaksud adalah sikap yang harus diambil oleh seorang pejabat publik ketika dirinya diduga terlibat atau bahkan ditetapkan sebagai tersangka dalam salah satu kasus, dengan melakukan pengunduran diri dari jabatan yang diembannya (nonaktif).

Budaya malu sebenarnya sudah banyak yang dilakukan oleh para pejabat publik di beberapa Negara maju ketika mereka menganggap dirinya merasa bertanggung jawab atas jabatannya, bahkan sebagian dari mereka mundur dari jabatannya hanya karena merasa dirinya gagal dalam menjalankan tugasnya dengan baik atau maksimal. Misalnya Negara Korea Selatan, dimana seorang Menteri ekonomi pengetahuan bidang energi mundur hanya karena hampir dua juta rumah warga negara di korsel mati selama satu jam. Selanjutnya PM Korea Chung Mong-Won juga menyatakan mengundurkan diri karena kejadian tenggelamnya kapal feri Sewoul, dimana keputusan itu diambil sebagai bentuk tanggung jawab kepala pemerintahan atas kejadian yang menewaskan 187 orang tersebut. Ada juga PM Yunani pada november 2011 mengundurkan diri lantaran merasa tidak mampu mengatasi keuangan negara dalam hal utang. PM jepang pada juni 2010 beberapa tahun lalu mengundurkan diri karena tidak mampu memenuhi janji politiknya. Negara Brasil yang baru tahun lalu sukses menggelar piala dunia tahun 2014 juga mengalami pengunduran diri beberapa pejabatnya, sedikitnya ada tujuh Menteri yang mengundurkan diri terkait dugaan kasus korupsi, berkaitan dengan tugas mereka masing-masing. Namun kita tidak menutup 
mata jika "budaya malu" juga terjadi di Indonesia dimana pada era kepemimpinan Pak SBY beberapa Pejabat Negara juga mengundurkan diri dalam Kabinet Indonesia Bersatu karena terlibat kasus Korupsi, seperti Menpora Andi Alfian Mallarangeng, Menristek Jero Wacik yang notabene adalah kader dari Partai Demokrat Pimpinan SBY sendiri, bedanya kemudian jika di Indonesia pejabatnya nanti mengundurkan diri ketika dirinya sudah ditetapkan tersangka, bahkan sebagian dari para pejabat yang berperkara masih tampil dengan tenang di depan layar kaca. Berbeda dengan beberapa Pejabat yang ada di Negara lain yang mundur ketika mereka baru diisukan terlibat dalam suatu kasus.

Kisruh yang terjadi antara dua Lembaga penegak hukum yakni POLRI vs KPK dalam beberapa hari terakhir, telah menimbulkan kegaduhan-kegaduhan yang semestinya bisa dihindari, belum lagi masyarakat/publik juga ikut bersuara dalam polemik yang terjadi di dua lembaga ini, bahkan sudah terbentuk faksi-faksi dimana sebagian ada yang mendukung langkah yang diambil KPK dalam penetapan tersangka calon Kapolri yang terlibat dugaan kasus Korupsi yang direspon oleh pengacara BG (Budi Gunawan) dengan mem pra peradilankan KPK, dan ada juga yang mendukung langkah POLRI dalam menetapkan para pimpinan KPK yang terlibat beberapa kasus. Beberapa pengamat pun juga sibuk memberikan pandangannya baik melalui tulisan di media cetak maupun tampil di beberapa stasiun TV. Beberapa kalangan menilai bahwa kisruh POLRI vs KPK tidak terlepas dari kepentingan politik dari para elite yang berada dibalik layar dari masalah yang terjadi.

Sudah sepantasnya Bangsa ini memiliki Pejabat Negara/Publik yang memiliki "budaya malu" dan harus mundur dari jabatannya ketika ia tersandung masalah ataupun kasus, selain untuk menunjukkan tanggung jawab moral ia sebagai pejabat yang beretika juga menghindari ketidakstabilan penegakan hukum di Negara ini. Permintaan pengunduran diri para pejabat publik yang tersandung masalah sudah disuarakan oleh beberapa pihak, baik itu menuntut Komjen Budi Gunawan untuk mengundurkan diri sebagai calon Kapolri juga menuntut para Pimpinan KPK untuk mundur dari jabatannya, khusus untuk Bambang Wijayanto, langkah yang diambil setelah dirinya ditetapkan sebagai tersangka adalah mengundurkan diri, selain karena inisiatif, aturan mengenai kode etik Pimpinan KPK jika terlibat dalam suatu perkara statusnya harus dinon aktifkan.

Para pejabat dan beberapa kalangan semestinya harus lebih bijak dalam melihat masalah ini, terutama bagi mereka yang bersikukuh beranggapan bahwa ada asas praduga tak bersalah (Presumption of Innocence) yang sudah lama dianut Bangsa ini, yang kemudian menjadi salah satu tameng kuat sehingga para pejabat publik yang terlibat masih menganggap dirinya masih pantas dan layak untuk tetap di posisinya. Mungkin sebagian pihak lupa atau bahkan tidak tahu bahwa Pejabat publik/Negara harus mengundurkan diri bukan hanya karena ia melanggar etika pejabat sebagai penyelenggara Negara tetapi sudah ada aturan ataupun mekanisme yang menjelaskan bagaimana status bagi pejabat publik yang sedang berperkara, dan melanggar etika . Sejak Tahun 2001 Majelis Permusyawaratan Rakyat (MPR), memberi dua Ketetapan No VI/MPR/2001, tentang etika kehidupan berbangsa dan TAP MPR No.VIII/MPR/2001 tentang arah dan rekomendasi pemberantasan KKN. TAP MPR No VI mengatur pejabat publik yang terkait atau terlibat kasus hukum, membuat kebijakan yang meresahkan atau mendapat sorotan publik, harus mau mengundurkan diri (dan dapat dimundurkan) tanpa harus dibuktikan lebih dulu oleh 
pengadilan. TAP MPR No VIII/2001 menegaskan, pejabat yang terlibat kasus hukum dapat dibebaskan dari jabatannya meski belum diputus pengadilan. Dalam salah satu tulisannya, Mantan Ketua MK Machfud MD, menjelaskan bahwa instrument hukum (Ketetapan MPR tersebut) dibuat berdasarkan pengalaman tentang banyaknya pejabat korup yang tak pernah mau mengaku saat kasusnya mulai diungkap, bahkan ikut bermain melalui judicial corruption, agar kasusnya tidak masuk ke pengadilan.

Jika melihat dari apa yang telah ditetapkan, sejatinya ketentuan itu sama sekali tidak melanggar hukum,HAM atau asas praduga tak bersalah yang berlaku umum. ketentuan ini merupakan tindakan administratif yang berlaku khusus bagi pejabat publik yang bermasalah dengan etika dalam kehidupan berbangsa dan bernegara, yang bersangkutan (pejabat publik yang bermasalah) dapat segera mundur atau dimundurkan, sementara proses hukumnya terus berjalan.

Harapan penulis dan mungkin juga sebagian besar masyarakat Indonesia semoga permasalahan yang terjadi antara dua lembaga penegak hukum ini dapat segera teratasi dengan baik, untuk menjaga stabilitas penegakan supremasi hukum, dan mengembalikan kepercayaan publik akan dua lembaga yang kita cintai ini, dan semoga "budaya malu" bisa muncul dikalangan para pejabat yang berperkara, untuk memperlihatkan bahwa mereka mengerti etika, dan aturan yang berlaku di Indonesia.

- Muh. Firyal Akbar

HP (085256265478)

Email : firyalakbar@yahoo.co.id 